International Journal of Humanities and Social Sciences p-ISSN: 1694-2620 | e-ISSN: 1694-2639

Vol. 13, No. 2 (2021), pp. 50-60, CIJHSS https://doi.org/10.26803/ijhss.13.2.3

Received June 19, 2021 | Revised September 28, 2021 | Accepted October 14, 2021

\title{
Human Capital, Economic Growth and Poverty Reduction Nexus: Why Investment in Free Compulsory Universal Education Matters for Africa
}

\author{
Yalley Josephine \\ Kwame Nkrumah University of Science and Technology, Kumasi, Ghana. \\ Email: Josephine_yalley@yahoo.com \\ Ogoe Francis \\ University Practice Senior High School, University of Cape Coast, Ghana \\ Email: fransswilogoe@yahoo.com \\ Moses Ackah Anlimachie \\ Education Futures, University of South Australia, Adelaide, Australia \\ moses.anlimachie@mymail.unisa.edu.au

\section{Cynthia Avoada} \\ Department of Geography and Rural Development, \\ Kwame Nkrumah University of Science and Technology, Kumasi Ghana. \\ avoadacynthia06@gmail.com
}

\begin{abstract}
This study uses a quantitative correlational design model to investigate the effects of human capital and economic growth on poverty reduction. The study sampled and analyzed 140 countries' data from United Nations Human Development Index report, 2010 to 2018. Comparing data from Africa, Europe and Asia, the study found that human capital had a positive effect on economic growth, while economic growth had a negative effect on poverty. The study argues that poverty reduction in Africa matters in creating sustainable global futures and recommends investment into free universal pre-tertiary education as a strategy to combat poverty.
\end{abstract}

Keywords: poverty; economic growth; human capital; human development; universal pre-tertiary education

\section{Introduction}

The threat that poverty poses to global sustainability continues to attract global concern and research commentary. The World Bank estimates that some 900 million people live below the poverty line (USD1.90 per day) globally as of 2015 (Dauda, 2017). Another two billion people suffer from multidimensional poverty relating to consumption, health and education (GSS, 2020). Africa, Asia and Latin America continue to be the most poverty endemic regions of the world 
(Burnell et al., 2017). Poverty reduction is, therefore, central to the United Nations Sustainable Development Goals (SDG). The SDG 1 rallies global effort in ending global poverty (Suleman, 2019).

According to Joshua (2019), poverty slows economic growth and breeds socioeconomic inequality. Conversely, economic growth is a powerful force to poverty reduction (Dollar et al., 2013; Dollar \& Kraay, 2002: World Bank, 2001). Pelinescu (2017) also argues that economic growth does not occur in isolation but is interrelated with human capital. Human capital development is thus a powerful tool for eradicating poverty.

This study adopts Pelinescu (2017) definition by operationally defining human capital as encompassing the abilities, skills, competencies, cultural capital and knowledge possessed by individuals that add value to and combine factors of production into productive economic activities that create wealth to increase the quality of life. Human capital accumulated through education, training and socialisation is the best impetus for or a means to wealth creation and poverty eradication.

Research evidence shows that increased investment in education and health correlated with increased economic growth, an indication that investment in human capital stimulates the productive sectors of the economy which, in turn, lowers unemployment levels while increasing income levels (Anlimachie \& Avoda, 2020; Holden \& Zhang, 2018; Nkechi \& Okezie, 2013). Stoker and Suri (2013) found that investment in human capital improved the economic growth of China and took 450 million people out of poverty.

Suffice to say that the kind and areas of investment in education or skill development are key to stimulating sustainable economic growth that can lift the masses out of poverty. Studying Ghanaian education and development context, Aryeetey (2015) and Amoako-Mensah et al. (2019) observed that, despite the significant progress made in poverty reduction, substantial levels of poverty prevailed in Ghana. This is because Ghana has a pool of skilled human resources both within the academia and industries, but has not been able to adapt skilled human resources to the most productive sectors, especially in agriculture and industrial processing sectors, to trigger spillover effects on sustainable jobs, or improved per capita income to eradicate poverty. Other Ghanaian commentators (Anlimachie, 2019; Amoako-Mensah et al., 2019) have linked this gap to the legacies of the colonial education system's white collar job and privileging mentality, which is not relevant to the Ghanaian economic context.

Poverty is endemic in African, an estimated $50 \%$ of the African population live below the poverty line (McKay, 2015; Wagstaff et al. 2018). While the global poverty level is reducing, the gap between Africa and other continents and the rural-urban poverty gap within Africa continues to widen (Brian, 2015; GSS, 2020). Empirically, the inter-linkage between human capital, economic growth and poverty has been extensively investigated globally. But more knowledge is required on the continue growing poverty gap between Africa and other continents and with regions in Africa. This study, using comparative socioeconomic data on Africa, Europe and Asia drawn from the UN Human Development Index (HDI) report seeks to analyze the nexus among human capital, economic growth and poverty to inform strategies for uplifting the masses of Africans from poverty.

The key research questions under investigation are:

1. What are the relationships between human capital, economic growth and poverty?

2. What are the effects of human capital on economic growth and poverty? 
The following research hypotheses were formulated:

$\mathrm{H}_{0}$ : There is a statistically insignificant relationship between human capital, economic growth, and poverty.

$\mathrm{H}_{1}$ : There is a statistically significant relationship between human capital, economic growth and poverty.

$\mathrm{H}_{0}$ : Human capital and economic growth have no significant effects on poverty.

$\mathrm{H}_{0}$ : Human capital and economic growth have significant effects on poverty.

\section{Literature Review}

\section{Theory review}

Human capital theory, endogenous growth theory and economic theory of poverty scaffolded this study in analyzing the relationships between education, economic growth and poverty reduction. The cardinal anchor of these theories is that investment in human capital through quality education and training maximises economic returns that trigger a spillover effect on improved productivity, income and quality of life.

\section{Human Capital Theory}

Human capital theorists like Jacob Mincer, Gary Becker, and Theodora Schultz argue that there is a correlative relationship between education and economic growth. The human capital theory is credited to Adam Smith, an 18th-century scholar, but it was popularised by Schultz (1961), Becker (1964), and Mincer (1974). Human capital theorists observed that investment in human capital increases the cognitive stock of economically productive human capability crucial for the individual to contribute maximumly to economic growth. The human capitalists draw inspiration from the standard and rational choice and theories by arguing that each labour has economic value. The extent of the economic value of labour is influenced by the level of human capital in terms of skills, knowledge, abilities attained through education. Therefore investment in education and training is a crucial impetus to economic growth (Holden \& Zhang, 2018; Marginson, 2019).

The fundamental principle underlying the theory of human capital is that people's expertise, capacities, and other resources involved in the creation of goods and services are of comparable value (Stefanova, 2019). The theory of human capital stipulates that investment in the abilities, expertise, skills and talents of people through education and training improves productivity as it makes labour more skilled and competitive, increasing the amount of cognitive stock of economically efficient human potential and productivity (Fleming, 2017).

Teixeira and Queirós (2016) conclude that investment in human capital is not only important for individuals but also essential to the economic growth of a country. As Fleming (2017) opined, the most valuable of all capital is that which is invested in human beings. Lee and $\mathrm{Vu}$ (2019) suggest that human capital plays a constructive and significant role in the economic cycle and large educational disparities affect productivity and economic development in the long term, as espoused in the endogenous growth theory.

\section{Endogenous Growth Theory}

The theory of endogenous growth, propounded by Romer (1984), provides a theoretical framework that emphasises economic growth as an endogenous outcome of an economic system, and not the result of forces like technological change that impinge from outside. Romer argues that a country with a greater accumulation of human capital has higher rates of economic growth (Roufagalas \& Orlov, 2020; Tavani \& Zamparelli 2017). The theory of endogenous growth has a neoliberalist perspective that investment in education is fundamental to economic growth, correlating to improve standards of living (Bonal, 2016; Gjorgjioska, 2019; Jensen, 2012).

Ahmad and Khan (2019), arguing from the endogenous growth perspective, observed that the determinants of economic growth essentially depend on the worth of human capital, which is 
contingent on investment in human development, including education and health. Marginson (2019) acknowledges that certain policy variables, like education subsidies, have a beneficial effect on long-term economic growth. Bella et al. (2019) assert that human capital as a factor of production impacts positively on economic growth, while Habib et al. (2019) elucidated that making human capital productive requires skills and knowledge that come out of education and training. Human capital encapsulates the acquired skill set, abilities and knowledge possessed by individual workers. According to Tavani and Zamparelli (2017), endogenous growth theory elevates knowledge or skills as a crucial economic variable as it drives inventions, discoveries and innovation that make other factors of production more effective. Baudino (2016), therefore, opined that investments in human capital have more lasting spillover effects on improved technology and economic output than investment in physical capital.

The above review of endogenous growth theory suggests that as labour accumulates human capital through education and training, productivity increases, income rises and poverty plummets.

\section{The economic theory of poverty}

The neoliberalists, led by John Maynard Keynes, argue that the market forces best instigate economic growth that best combat poverty; therefore, private sector-led education and training is most efficient in maximising human capital formation, economic growth and, thus, poverty reduction compared to state-led welfare interventions (Winston, 2018). Jenson, (2012), Holden and Zhang (2018) and Urgaia (2018) see public investment in education as a social good. Therefore, approaching education from a welfare perspective is significant in accumulating social, cultural, physical and human capital, especially in low-income communities to drive economic development towards poverty reduction. A fine balance between economic returns and social safety net approaches to education can better translate into economic growth that impacts all social classes (Jenson, 2012). Jones (2019) adds that investment in education or training is the best investment that facilitates the individual transition from low to high socioeconomic status. The economic theory of poverty, therefore, problematises poverty reduction as an interconnection between human capital and economic growth.

\section{Empirical review}

There is an extensive research literature on the impact of human capital on economic growth and poverty). Studies by Abbas (2001), Mattalia (2012), Addison et al. (2016), Adekoya (2018), Pavlova (2018), Picatoste et al., (2018), Ahmad and Khan, (2019), Olopade et al. (2019) and Collin and Weil (2020), found that investment in human capital has a correlative effect on economic growth and poverty reduction. Adekoya's (2018) investigation on the impact of human capital development on poverty alleviation in Nigeria found that investment in education and health by the Nigerian federal government resulted in a reduction of poverty.

Also, investigating human capital and poverty reduction strategies in OPEC countries, Olopade et al. (2019) found long-run interactive effects of the components of human capital development on poverty reduction. The authors thus argue that human capital is a crucial determinant of improving economic growth and rallied OPEC member countries to invest in education and improved healthcare to ignite and leverage the full potential of human capital, as a substitute for oil wealth, which is will become extinct shortly. The finding is also supported by Collin and Weil (2020) that investing in people offers a much more cost-effective pathway to economic sustainability than investing in physical capital when development strategies focus on income or poverty goals (Olopade et al., 2019).

Mattalia (2012) used a model based on endogenous growth to investigate human capital accumulation as a factor of economic growth and found schooling or training as a more potent factor in impacting productivity and, thus, economic growth than other areas of investment. 
Abbas (2001) used the OLS method to study the causal relationship between human capital and economic growth using longitudinal data from Sri Lanka and Pakistan. The study identified a significant positive impact of secondary and higher education on economic growth but an insignificant impact of primary education on economic growth, a suggestion that secondary and higher education offer the best sector of education investment to lift economic growth to reduce poverty (Abbas, 2001). Abbas' cold feet to investment in primary education approach as a means to ignite economic growth contradicts Anlimachie and Avoada (2020) and Amako-Mensah et al. (2019) studies on Ghana which found that investment into pre-tertiary education, including primary education, best increases rural labour force, agriculture productivity, and reduces ruralurban socioeconomic inequality, crucial to uplifting rural agrarian communities from poverty.

\section{Methodology}

Informed by the above theoretical and empirical review, this study adopted a conceptual framework (see Figure 1) hypothesising human capital and economic growth as influencers on poverty reduction. Thus, in this study, human capital and economic growth are characterised as independent variables, while the dependent variable is poverty. The figure shows the interconnection between human capital, economic growth and poverty. From the diagram, it can be observed that human capital is the product of human investment leading to the development of skills, expertise, abilities, talents, and skills that stimulate higher incomes and economic growth and higher economic growth is thus seen as a panacea for poverty reduction.

\section{Study design}

A quantitative research approach framed as a correlational study design was adopted to ground the study on sound scientific evidence informed by the positivist research tradition. The approach uses hard-core evidence to seek regularities and causal relationships that characterise the social world (Burrell \& Gareth, 1992; Creswell, 2021; Creswell \& Plano Clark, 2011).

According to Brewer (2007), correlational designs are based on comparing the distribution of scores dispersed along two dimensions. Secondary data from 2010 to 2018 on human capital (measured as a percentage of the skilled labour force) from Human Development Index Report, economic growth (measured as GDP per capita) as well Poverty Headcount (measured as the population with a deprivation score of at least 33\% from Human Development Index Report were used in the analysis. A sample of 140 countries was selected from a population of 189 countries from Africa, Europe and Asia.

Concerning the analysis, Statistical Product and Service Solutions (SPSS Version 21) and Microsoft Excel (2013) were used to generate descriptive statistics, Pearson Product-moment correlation and multiple regression analysis. A variable continent was generated. Africa continent was given the value 1, Europe was given 2 and the Asian continent was given the value 3 . The results are presented in the next section.

\section{Results}

This section uses descriptive statistics, Pearson-product moment correlation analysis and multiple regression analysis to examine the poverty, human capital and economic growth nexus. The variables include skilled labour force, GDP per capita and poverty headcount. The study used a total of 140 countries that were drawn from Africa, Europe and Asia. The sample size varied from issue to issue as a result of non-response.

The study examines the skilled labour force in Africa, Europe and Asia because investment in human capital is seen as a powerful force for poverty reduction. The descriptive statistics revealed that the median skilled labour force in Africa was 20.00 (mean $=27.665$; std. deviation $=21.1739$; skewness $=1.015$ ) with a quartile deviation of 14.75. Europe had median skilled labour force of 
85.00 (mean $=82.08$; std. deviation $=12.843$; skewness $=-1.274)$ with an associated quartile deviation of 6.4. The mean skilled labour force for Asia was 48.730 (median= 39.00; quartile deviation $=25.3$; skewness $=0.431$ ) with a standard deviation of 26.943. The minimum skilled labour force was 13.0 and the maximum skilled labour force was 95.0.

The study further investigates the rates of economic growth. The results of the descriptive statistics show that the median GDP per capita for Africa was $\$ 3,051.690$ (mean $=5358.678$; std. deviation $=5738.5324$; skewness $=1.821$ ) with an associated quartile deviation of 2673.6. Europe had a median GDP per capita of $\$ 31,134.472$ (mean $=34848.696$; std. deviation $=18338.0070$; skewness $=1.146$ ) with a quartile deviation of 11703.3. With respect to Asia, the median GDP per capita was $\$ 11,136.250$ (mean $=21950.143$; std. deviation $=25544.7$; skewness $=1.838$ ) with a quartile deviation of 12085.7. The median GDP per capita indicates that Europe experienced high economic growth due to an increase in human capital.

The study further examined the poverty headcount in Africa, Europe and Asia. As indicated, poverty is not endemic only in Africa, but in Asia. The mean poverty headcount in Africa was 48. 96 (median $=52.33$; quartile deviation $=19.45$; skewness $=-0.282$ ) with a standard deviation of 25.68. The minimum poverty headcount was 1.3 and the maximum was 91.9. The median poverty headcount in Europe was .700 (mean $=1.048$; std. deviation $=.9365$; skewness $=1.016$ ) with an associated quartile deviation of 0.95 . With respect to Asia, the median poverty headcount was 7.42 $($ mean $=17.36$; std. deviation $=18.55$; skewness $=0.734)$ with a quartile deviation of 18.3. The results confirm a report by UNESCO Institute for Statistics (2019) as well as the United Nations Statistics Division (2019b) and World Bank (2019a) that poverty is pervasive in Africa.

\section{Association between human capital, economic growth and poverty}

The relationship between human capital as measured as the percentage of the skilled labour force and economic growth as measured as the Gross Domestic Product Per Capita was first investigated using the Pearson product-moment correlation coefficient. Initial analyses were performed to ensure no violation of the assumptions of normality, linearity and homoscedasticity. As noted from Table 2, there is a large, but positive significant relationship between human capital and economic growth $(\mathrm{r}=0.531, \mathrm{p}=0.0000)$. The explanation for this is that building the capacity of people equips them with skills, competencies, abilities and talents, which stimulate economic growth. The finding is also supported by the conceptual framework's illustration on human capital and economic growth nexus and is consistent with endogenous growth theory's assertion that the accumulation of human capital stimulates higher economic growth (Teixeira \& Queirós, 2016).

Table 1: Correlation matrix: the variables

\begin{tabular}{llll}
\hline & SkiLaForce & GNP & PovHC \\
\hline Skillab force & 1 & & \\
GNP & $.531^{* *}$ & 1 & \\
POvHC & .000 & $-.547^{* *}$ & 1 \\
& $-.725^{* *}$ & .000 & \\
\hline
\end{tabular}

Source: HDR data (2018)

The relationship between human capital as measured as the percentage of the skilled labour force and poverty as measured as the population of deprivation score of at least $33 \%$ was investigated using Pearson product-moment correlation coefficient. As noted from the correlation matrix in Table 1, there is a large but negative significant correlation between human capital and poverty ( $\mathrm{r}$ $=-.725, \mathrm{p}=0.0000$ ). Thus, implying that increases in human capital accumulation result in poverty reduction. The relationship observed between human capital and poverty is consistent with studies 
by Addison et al.(2016) that investment in human capital is viewed as a panacea for poverty reduction.

Concerning the relationship between economic growth and poverty, the Pearson product-moment correlation coefficient was computed to analyse the relationship between the variables. As depicted from the correlation matrix in Table 1 , there is a large, but negative statistically significant relationship between economic growth and poverty $(\mathrm{r}=-0.547, \mathrm{p}=0.0000)$. This indicates that a sustained increased in the GDP per capita results in poverty reduction. The observation that economic growth affects poverty corroborates the findings of Berg and Ostry (2017) that economic growth is the most effective indicator to reducing poverty. It equally supports the proposition of the economic theory of poverty that growth in income and productivity constitute key components in poverty reduction.

\section{Effects of human capital and economic growth on poverty}

Table 2 presents the results of multiple regression analysis performed on poverty as a dependent variable and two independent variables: human capital and economic growth. Preliminary analyses were performed to ensure that there was no violation of assumptions of normality, homoscedasticity and collinearity.

From the regression results, jointly, the two variables have statistically significant effects on poverty, $\mathrm{F}(2,62)=44.577, \mathrm{p}<.05, \mathrm{R}^{2}=.590$.

This implied that $59 \%$ of the variation in poverty was attributed to the combined variations in human capital and economic growth. The variable human capital was hypothesised to relate to poverty with a negative effect. The regression results revealed a negative coefficient of -.601 and a statistically significant $(\mathrm{p}=0.00)$ effect of human capital on poverty. The coefficient results implied that a unit increase in human capital will decrease poverty by about -.601. The observed relationship between human capital and poverty in the study supported the hypothesis that human capital influences poverty while refuting the null hypothesis that human capital does not influence poverty. The finding of the study is consistent with the findings of Adekoya (2018) that human capital is believed to be the basis for economic prosperity and poverty reduction.

Table 2: Regression output

\begin{tabular}{|c|c|c|c|c|c|}
\hline \multicolumn{6}{|l|}{ Coefficients } \\
\hline \multirow[t]{2}{*}{ Model } & \multicolumn{2}{|c|}{$\begin{array}{l}\text { Unstandardised } \\
\text { Coefficients }\end{array}$} & $\begin{array}{l}\text { Standardised } \\
\text { Coefficients }\end{array}$ & $\mathrm{T}$ & Sig. \\
\hline & $\overline{\mathrm{B}}$ & Std. Error & Beta & & \\
\hline (Constant) & 62.012 & 3.824 & & 16.215 & .000 \\
\hline SkillabForce & -.601 & .096 & -.582 & -6.247 & .000 \\
\hline GNP & -.001 & .000 & -.292 & -3.132 & .003 \\
\hline
\end{tabular}

\begin{tabular}{ll}
\hline \multicolumn{2}{l}{ Collinearity Statistics } \\
\hline Tolerance & VIF \\
\hline .762 & 1.312 \\
.762 & 1.312 \\
\hline
\end{tabular}

Economic growth was hypothesised to poverty with a negative effect (World Bank, 2001). The results from the regression analysis revealed a negative coefficient of -.001 and a statistically significant effect $(\mathrm{p}=.003)$ of economic growth on poverty. The coefficient results implied that a 
unit increase in the rate of growth of an economy decreases poverty by -.001 when all other factors are held constant. The finding that economic growth negatively influenced poverty supports the economic theory of poverty and Addison et al. (2016) proved per capita income increases health status and the level of education, leading to a declining in poverty. Therefore, economic growth reduces the level of poverty.

Based on the regression results, the empirical model was derived. The poverty equation is fitted as Poverty $=62.012-.601$ Human capital -.001 Economic growth

The coefficients in the model indicate that human capital and economic growth inversely affect poverty. This implies that an increase in any of the variables will cause a decrease in poverty given a constant of 62.012 .

From the regression output, human capital makes the strongest unique contribution to explaining the dependent variable. The Beta value for human capital was $(-.582) \mathrm{m}$ indicating that it is the best predictor to explain poverty. Economic growth makes the lowest contribution with a Beta value of (-.292).

\section{The effect of universal education on poverty reduction}

This section uses the case of Ghana to analyse the effect of universal pre-tertiary education provision on human capital, economic growth and reduction of poverty, using a comparative analysis of the agricultural and industrial sectors. Agriculture in Ghana is mostly rural and practiced at the subsistence level. The industrial sector on the other hand is mostly concentrated in the urban areas towards the Atlantic coast.

The percentage of the workforce engaged in agriculture in Ghana is about $52 \%$. Yet agriculture accounts for only $22 \%$ of the GDP, an indication of the low productivity of the agricultural labour force in Ghana. In contrast, the industrial sector ${ }^{1}$ employs only $11 \%$ of Ghanaians, which is about one-fifth of the agricultural labour force, yet it also adds 22\% to Ghana's GDP (Adjei et al., 2020; Amoako-Mensah et al., 2019; Anlimachie, 2019; Anlimachie \& Avoada, 2020; GLSS7, 2018). The low productivity in the agriculture sector is because only $15 \%$ of the agricultural workforce, mostly rural people, has a secondary education, compared with some $48 \%$ for the industrial workforce.

The low agricultural productivity in Ghana translates to high poverty incidence $(80 \%)$ in rural Ghana compared to $20 \%$ for the urban population in Ghana (FAO, 2012; GLSS7, 2018; GSS, 2012). This suggests the low productivity and high poverty among the rural population in Ghana. This is corroborated by the seventh Ghana Living Standard Survey (GLSSL7) report that rural poverty increases with lower educational attainments among rural households (GLSSL7, 2018). Therefore, this study estimates investment in pre-tertiary education to increase (triple) the secondary educational attainments for rural workforce from the current $15 \%$ to the same level $(48 \%)$ of the urban workforce will correspondingly triple rural agricultural output. This translates to some $23 \%$ increase in the agriculture share to Ghana's GDP, correlative to a $50 \%$ reduction in the poverty incidence in Ghana.

The prospect of investment in the provision of free universal pre-tertiary education as a strategy to combat poverty in African can also be traced in the analysis of Ghana's Human Capital Index (HCI). Ghana's HCI is estimated at 0.44 , meaning that a child born in Ghana today will be $56 \%$ less productive when she grows up as he/she could be if he/she had complete education and full health (ESA, 2019; WorldBank, 2018). Ghana's HCI correlates with its 'number of qualityadjusted learning years' of just 5.7 years out of the 11.6 average years of schooling in Ghana by age 18 (World Bank, 2018, p.4). Therefore, improving education to doubling the numbers of the quality-adjusted learning years in Ghana through education investment and relevant strategies can

${ }^{1}$ Some $80 \%$ of manufacturing industries in Ghana are in the urban areas towards the Atlantic coast. 
also double Ghana's GDP and half the country poverty levels. The above evidence, corroborate other studies (Anlimachie, \& Ativi, 2020; Amoako-Mensah et al., 2019; Fuseini et al. 2019; Mbuli, 2008) suggesting that investment in free compolsory universal pre-tertiary education matters in Africa as it offers the best and the most immediate strategy for increasing human capital and economic growth to reduce poverty.

\section{Conclusions and policy implications}

From the analysis, investment in education and training accumulates and increases human capital. This, in turn, sparks economic growth to reduce poverty. The study showS evidence that Africa has the lowest percentage of the skilled labour force compared to other continents, contributing to high poverty levels in Africa. The evidence from Ghana, corroborateS the comparative analysis of the African and other continents to make the case that investment into human capital and development, especially the provision of universal free pre-tertiary education, offers the immediate strategy to improving human capital and economic growth to reduce the continent's higher poverty levels. Especially among rural agrarian communities.

Investment in free universal pretertiary education as a poverty reduction strategy matters for Africa. Therefore, there is the need to incorporate free universal education strategies from primary to upper secondary level, in the meantime while working on sustainable policies and funding towards progressively free tertiary education to nurture highly skilled human capital to drive the continent's economic development to eradicate poverty in line with the SDGs.

\section{References}

Abbas, Q., \& Nasir, Z. M. (2001). Endogenous growth and human capital: A comparative study of Pakistan and Sri Lanka. The Pakistan Development Review, 12(3), 987-1007.

Addison, T., Gisselquist, R. M., Niño-Zarazúa, M., \& Singhal, S. (2016). Needs vs expediency: Poverty reduction and social development in post-conflict countries. Building sustainable peace: Timing and sequencing of post-conflict reconstruction and peacebuilding. Oxford: Oxford University Press

Adjei, V., Anlimachie, M. A., \& Ativi, E. (2020). Understanding the Nexus between Climate Change, the Shift in Land Use toward Cashew Production and Rural Food Security; The Experiences of Farmers in the Transition Zone of Ghana. Journal of Atmospheric Science Research, 65, 65881289. https://doi.org/10.30564/jasr.v3i2.2010

Ahmad, M., \& Khan, R. E. A. (2019). Does demographic transition with human capital dynamics matter for economic growth? A dynamic panel data approach to GMM. Social Indicators Research, 142(2), 753-772.

Ahmed, E. M. (2017). ICT and human capital spillover effects in achieving sustainable East Asian knowledge-based economies. Journal of the Knowledge Economy, 8(3), 1086-1112.

Amoako-Mensah, T., Anlimachie, A. M., Adu, B. S., \& Elorm, E. A. (2019). Out-migration and the Double Jeopardy of rurality in Ghana. An integrated approach to rural development. European journal of geography, 10(1), 50-67. https://find.library.unisa.edu.au/primoexplore $/$ fulldisplay?vid=UNISA\&search_scope=All_Resources\&docid=UNISA_ALMA 11190217220001831

Anlimachie, M. A. (2019). Enacting Relevant Basic Education to Bridge the Rural-Urban Inequality in Ghana; The Prospects and Approaches for Investigating Rural Educational Realities. International Journal of Humanities and Social Sciences, 11(1), 42-58.

Anlimachie, M. A., \& Avoada, C. (2020). Socio-economic impact of closing the rural-urban gap in pre-tertiary education in Ghana: context and strategies. International Journal of Educational Development, 77(102236), 1-12. doi:10.1016/j.ijedudev.2020.102236

Aryeetey, E. (2015). The informal economy, economic growth, and poverty in Sub- Economic growth and poverty reduction in Sub-Saharan Africa: Current demerging Issues. Working 
Paper No. 15). University of Ghana, Legon: Institute of Statistical, Social and Economic Research, (ISSER).

Baudino, M. (2016). The impact of human and physical capital accumulation on Chinese growth after 1994: A spatial econometric approach. World Development Perspectives, 2(5), 11-16.

Bella, G., Mattana, P., \& Venturi, B. (2019). Globally indeterminate growth paths in the Lucas model of endogenous growth. Macroeconomic Dynamics, 5(4), 1-12.

Berg, A. G., \& Ostry, J. D. (2017). Inequality and unsustainable growth: Two sides of the same coin? IMF Economic Review, 65(4), 792-815.

Bonal, X. (2016). Education, poverty, and the "missing link": The limits of human capital theory as a paradigm for poverty reduction. In K. Mundy, A. Green, B. Lingard, \& A. erger (eds.), The handbook of global education policy, pp.97-110. Hoboken, New Jersey: John Wiley \& Sons.

Brewer, R. C. (2007). Your PhD Thesis: How to plan, draft, revise and edit your thesis. Studymates. Abergele, United Kingdom: Studymates Limited.

Brian, K. (2015). OECD insights income inequality the gap between rich and poor: The gap between rich and poor. Paris: OECD Publishing.

Burnell, P. J., Rakner, L., \& Randall, V. (2017). Politics in the developing world. Oxford: Oxford University Press.

Burrell, G., \& Gareth, M. (1992). Sociological Paradigms and Organisational Analysis. Part I - In Search of a Framework. Burlington, MA: Ashgate.

Collin, M., \& Weil, D. N. (2020). The effect of increasing human capital investment on economic growth and poverty: A simulation exercise. Journal of Human Capital, 14(1), 43-83.

Creswell, J. W., (2021). Educational Research: Planing, Conducting, and Evaluating Quantitative and Qualitative Research, Sixth edn, Pearson Education Limited, United Kingdom.

Creswell, J. W., \& Plano Clark, V. L. (2011). Designing and conducting mixed methods research (2nd ed.). Los Angeles: SAGE Publications.

Dauda, R. S. (2017). Poverty and economic growth in Nigeria: Issues and policies. Journal of Poverty, 21(1), 61-79.

Dollar, D., \& Kraay, A. (2002). Growth is good for the poor. Journal of Economic Growth, 7(3), 195225.

Dollar, D., Kleineberg, T., \& Kraay, A. (2013). Growth still is good for the poor. Washington, DC: The World Bank.

ESA. (2019). Ghana Education Sector Analysis, 2018. Ministry of Education, Ghana, Accra. Accra: Ministry of Education, Ghana. https://www.globalpartnership.org/sites/default/files/2019-05-ghana-education-sectoranalysis.pdf

Fleming, P. (2017). The human capital hoax: Work, debt and insecurity in the era of Uberization. Organization Studies, 38(5), 691-709.

Fuseini, M. N., Enu-Kwesi, F., \& Sulemana, M. (2019). Poverty reduction in Upper West Region, Ghana: role of the Livelihood Empowerment Against Poverty programme. Development in Practice, 29(6), 760-773.

GLSS7. (2018). Ghana Living Standard Survey Round 7. Accra, Ghana: Ghana Service (GSS). http://www.statsghana.gov.gh/docfiles/publications/GLSS7/Poverty\%20Profile\%20Re port_2005\%20-\%202017.pdf

Gjorgjioska, M. A., \& Tomicic, A. (2019). The crisis in social psychology under neoliberalism: Reflections from social representations theory. Journal of Social Issues, 75(1), 169-188.

GSS. (2020). Multidimensional Poverty - Ghana. Accra.

Habib, M., Abbas, J., \& Noman, R. (2019). Are human capital, intellectual property rights, and research and development expenditures really important for total factor productivity? An empirical analysis. International Journal of Social Economics, 46(6), 758-774.

Holden, R., \& Zhang, J., 2018. The economic impact of improving regional, rural and remote education in Australia. Gonski Institute for Education (UNSW). 
Jenson, J. (2012). Redesigning citizenship regimes after neoliberalism: Moving towards social investment. Towards a social investment welfare state? Ideas, policies and challenges, (Working Paper No. 61). Stockholm, Sweden: Institute for Futures Studies.

Joshua, J. (2019). The Belt and Road Initiative and the Global Economy. Cham, Switzerland: Palgrave Macmillan.

Marginson, S. (2019). Limitations of human capital theory. Studies in Higher Education, 44(2), 287301.

Mbuli, B. N. (2008). Poverty reduction strategies in South Africa [Doctoral dissertation]. University of South Africa, South Africa.

McKay, A., \& Thorbecke, E. (Eds.). (2015). Economic growth and poverty reduction in sub-Saharan Africa: Current and emerging issues. Oxford: Oxford University Press.

Olopade, B. C., Okodua, H., Oladosun, M., \& Asaleye, A. J. (2019). Human capital and poverty reduction in OPEC member countries. Heliyon, 5(8), 22-79.

Pavlova, M. (2018). Fostering inclusive, sustainable economic growth and "green" skills development in learning cities through partnerships. International Review of Education, 64(3), 339-354.

Pelinescu, E. (2017). The buman capital and development. The Romanian case study (Working paper No. 170702). Romania: Institute for Economic Forecasting.

Pelinescu, E., Pauna, C., Saman, C., \& Diaconescu, T. (2019). Human Capital, Innovation and Economic Growth in the EU Countries. Journal for Economic Forecasting, 2(4), 160-173.

Picatoste, J., Pérez-Ortiz, L., \& Ruesga-Benito, S. M. (2018). A new educational pattern in response to new technologies and sustainable development. Enlightening ICT skills for youth employability in the European Union. Telematics and Informatics, 35(4), 1031-1038.

Roufagalas, J., \& Orlov, A. G. (2020). Endogenous growth, human capital and the dynamic costs of recessions. Journal of Economic Studies, 47(2), 264-285.

Tavani, D., \& Zamparelli, L. (2017). Endogenous technical change in alternative theories of growth and distribution. Journal of Economic Surveys, 31(5), 1272-1303.

Teixeira, A. A., \& Queirós, A. S. (2016). Economic growth, human capital and structural change: A dynamic panel data analysis. Research Policy, 45(8), 1636-1648.

UNESCO Institute for Statistics (UIS). (2019). Global development indicators, 2019. Analysis of data from 198 countries: Paris: UNESCO PublicationsUrgaia, W. R. (2018). The role of human capital resources in East African Economies (Working paper No. 218). Maastricht, Netherlands: Global Labour Organization.

Wagstaff, A., Flores, G., Smitz, M. F., Hsu, J., Chepynoga, K., \& Eozenou, P. (2018). Progress on impoverishing health spending in 122 countries: A retrospective observational study. The Lancet Global Health, 6(2), 180-192.

Winston, A. S. (2018). Neoliberalism and IQ: Naturalizing economic and racial inequality. Theory \& Psychology, 28(5), 600-618.

World Bank. (2019). Human development reports index. Washington, DC: The World Bank.

World Bank. (2018). Ghana Accountability for Learning Outcomes Project (P165557). The World Bank. http:// projects.worldbank.org/P165557?lang=en 